\title{
charting our future
}

Julie Todaro

\section{The power of persuasion Grassroots advocacy in the academic library}

A fter years of working in the local, state, and national legislative arena, for me, the term advocacy has become-admittedly incorrectly-synonymous with primarily external advocacy for legislative initiatives. It's hard work, it takes a wide variety of talents, great stamina, and-obviously-it is an ongoing and often uphill, frustrating road. It's no wonder that burnout among legislative advocates is high and that the term advoca$c y$-no matter the meaning-is not always first on everyone's to do list.

With this in mind, before the last Texas legislative session and before Texas initiatives at the federal level, I explored ways to bring new supporters to the legislative table as well as ways that might rejuvenate the experts who had faithfully come to the Texas process for many years. Given our $24 / 7$, major ongoing commitment to proactive legislative contact, rather than our annual moderate activity with extensive work every two years during the session, I chose to focus on training advocates with skills that would serve those involved throughout the legislative year, between legislative sessions as well as back in the workplace. I decided to move away from the term advocacy for recruiting and training legislative and instead focus on in uence and persuasion.

My rationale was, and still is, no matter who we are trying to influence, we have so little time with those we are trying to convince and-as in other professions-people in legislative arenas and in our own institutions really know very little about what we do. Realistically speaking, sitting down with a legislator, a legislative aide or, for our initiative at hand, a department chair, dean, or even classroom faculty for 15 minutes at a time (no matter the educational content we bring) is a matter of getting attention, creating a teachable moment, indicating value and worth of what we do, making an impact, connecting with a promised outcome or a memorable, unique or targeted fact, and seeking followup opportunities.

In addition, learning how to influence and persuade through longer moments, such as work on curriculum design projects with classroom faculty, in working with students daily at the reference desk, through working with student leaders for institutional projects and partnerships and in typical bibliographic and educational support activities, are all avenues for integrating critical support for library value, worth, and initiatives.

\section{Training library advocates}

In searching for training content, I found Robert Cialdini's and his Cialdini s In uence: Science \& Practice. ${ }^{1}$ His practical and scholarly work in the psychology of influence, offers extraordinary opportunities for learning and applying influence and persuasion principles for professionals in a wide variety of work environments. I ordered a video presentation, obtained permission to use the video in training our Texas legislative network, and, for several years, have been convinced of his unique message for convincing and persuading others to "our side" for both our "teachable moments" and for our more extensive work relationships and opportunities.

Julie Todaro is dean of library services at Austin Community College, e-mail: jtodaro@austincc.edu

๑ 2006 Julie Todaro 
How does this relate to our future, Camila Alire's presidency, and ACRL goals overall? Alire's vision for her presidency is an exciting, multifaceted view that includes a commitment to expanding opportunities to develop frontline librarians. ${ }^{2}$ In her own words, under her "Charting our future: Advocacy to advance academic libraries" umbrella, "No matter what positions we hold in our libraries, our responsibilities seem to be ever-changing as we face increasing challenges, such as the reality of reduced funding, the demand for more electronic resources and services, the expectation to lead scholarly communication discussion and action, the certainty of retirements en masse, and the challenge to diversify our institutions and academic libraries' workforce, among others." During her presidency, she has been focusing on one of ACRL's strategic areas of focus-advocacy-but specifically grassroots advocacy that includes training frontline librarians and other library workers "to strengthen their influence on their local campuses in campus awareness and activity related to public policy affecting higher education." 3

In discussions with frontline librarians and middle managers about ACRL goals, however, the reality is that librarians-although they are overall supportive of future directions-do not have extensive training in influencing, persuasion, or even advocacy, much less the science of influence or persuasion. Although learning the science and art doesn't free up time and doesn't automatically create venues for communicating new techniques or knowledge, learning how to influence and persuade:

- helps to identify institutional issues and avenues where persuasion and influence might work best;

- provides tools to identify individuals with whom techniques of persuasion and influence might work best;

- outlines content focusing on value and worth to design and enhance the academic library message;

- illustrates the value and application of passion and commitment in using techniques of influence and persuasion;
- provides skills sets to increase basic skills and instill confidence in both new and expert advocates;

- identifies the elements of empowerment and leadership for advocating for the library at the campus level;

- builds on the existing strength, competency, and credibility of frontline librarians; and

- offers content to be used in designing a systematic advocacy action plan to inform faculty, students, and (where appropriate) academic administrators and institutional partners about academic library issues.

\section{Learn how at the ACRL advocacy workshop}

Alire's vision, realized through the design of a workshop and toolkit to be premiered in New Orleans, is designed to address the levels of advocacy, desire, and determination by assisting librarians to identify roles they might play in choosing to get involved with advocacy efforts through the application of influence and persuasion techniques; identifying librarians who are best suited to the process as well as certain audiences in the process; teaching "the choir" new ways to connect; and illustrating how to integrate influence and persuasion into work responsibilities and goals for the institution.

Members are strongly encouraged to attend the 2006 ALA program "The Power of Personal Persuasion: Advocating for the Academic Library Agenda from the Frontlines." I think you will find the content both practical and inspirational, and you will go home with extensive content for advancing your institution "from the frontlines."

\section{Notes}

1. Robert Cialdini, "Influence at work: The psychology of persuasion," Influence at Work, N.d. 17 January 2006, www.influenceatwork. com/index.htm.

2. Camila A. Alire, "Charting our future: Advocating to advance academic libraries: The 2005-06 ACRL President's focus," CERL

(continued on page 268) 
finally, director of fiscal and administrative services.

Wayne Gossage, library director, management consultant, entrepreneur, and executive recruiter in the New York metropolitan area from 1950 to 2003, has died. Gossage worked in public libraries in East Orange, New Jersey, and Levittown, New York, before serving as director of the Warner Library in Tarrytown NY (1955-1963); as assistant director of Teachers College Library, Columbia University (1963-67); and as director of Bank Street College of Education Library (1967-80). He served on several alumni and professional organizations, notably as an active member of the New York Library Association and ALA; trustee of the Harvard Library NYC (1978-2000); and Board advisor, Pratt Institute School of Information and Library Sciences (1988-2001). Beginning in 1983, he was the first executive search consultant for directors of public library systems and for university deans of libraries. In 1980, Wayne Gossage and Muriel Regan formed Gossage Regan Associates (now Gossage Sager Associates, Inc.) for library management consulting, which also was the first library personnel firm specializing in temporary services.

John P. McGowan, 79, retired university librarian at Northwestern University, has died. McGowan was known for leading Northwestern's library from a traditional repository of

\begin{tabular}{lr}
\multicolumn{2}{c}{ Advertisers } \\
AARP & 220 \\
ACM & 265 \\
Annual Reviews & 256 \\
ARL & 263, cover 3 \\
Chemical Abstracts Service & cover 2 \\
Choice & 259 \\
EBSCO & cover 4 \\
Frugal Librarian & 254 \\
Haworth & 212 \\
Library Technology Alliance & 255 \\
Project Muse & 227 \\
RBMS & 215 \\
Thompson Gale & 211
\end{tabular}

books to a library of automation and information technology. In 1951, McGowan became a librarian in New York University's College of Engineering, and later joined Northwestern in 1956 as librarian of its Technological Institute. In 1959 he left Northwestern to become library director at the Franklin Institute in Philadelphia; he returned to Northwestern in 1966 as associate university librarian. He was later promoted to university librarian in 1971, serving in that position until he retired in 1992. McGowan was the 1989 ACRL Academic/Research Librarian of the Year. $\boldsymbol{z}$

("The power of persuasion," cont. from page 229)

News 66, no. 8 (2005), 26 February 2006, www.ala.org/ala/acrl/acrlpubs/crlnews $/ \mathrm{b}$ a c kis sues $2005 / \mathrm{september0} 5$ /advocatingtoadvance.htm.

3. Camila Alire, "President's Page: Message from Camila," ACRL, 2005. American Library Association. 1 March 2006, www.ala.org/ala/acrl/presidentspage /presidentspageacrl.htm. n

("Reviews" continued from page 261)

tion, date, or event. An additional means of access is through the teacher resource pages, where curricular material is provided for five well-designed thematic lesson plans that are designed to work with the digital collection while delving further into such issues as immigration, child labor, and domestic work. The homepage features a changing display of images and diary entries and related resources that include several of Harvard's digitization partners, such as the Library of Congress.

Women Working, 1800-1930, is an extensive, subject-based collection of unique and rare items that is well-designed, easily accessible, and thoroughly fascinating. In its depth, breadth, and design, which is as informative as it is educational, it is a model for other digital collections._Linda Frederiksen, Washington State University Vancouver, frederik@vancouver.wsu.edu $n$ 